http://dx.doi.org/10.4314/ejotmas.v7i1-2.22

\title{
CHOREOGRAPHIC METAPHORS OF POLITICAL TERRORISM AND COUNTER-TERRORISM IN ARODAN DANCE THEATRE
}

\author{
*Tosin Kooshima TUME, Ph.D.
}

\begin{abstract}
In Nigeria, the deliberate intimidation and exploitation of the common man by the ruling class, for political aims, has reached endemic proportions. These strategic intimidations come in diverse forms, and clearly qualify as acts of terrorism. In the Yoruba worldview, 'Arodan' is a cautionary concept which is employed by the elders to curb the excesses of troublesome children. However, it has evolved to be a two-edged sword which could either be used for both corrective and curative aims, or manipulated for punitive and evil purposes. Arodan, a dance workshop performance by the students of the Department of Theatre and Media Arts, FUOYE, is built on the Yoruba conceptual frame of 'Arodan'. The dance theatre is a metaphor which explores the 'Arodan' concept to identify Nigerian politicians as the 'elders', and the common man as the 'troublesome child.' Deploying the social identity theory (SIT), this article, examines the use of choreographic metaphors to enact the forms, features, and effects of political terrorism within the Nigerian space in the Arodan performance. It finds that the desperate yearnings which stem from selfish political interests are cloaked under terrorist acts in Nigeria. In conclusion, the paper affirms that the resolutions simulated in Arodan - national reorientation, political awareness, vigilance, and collective will should be deployed as proactive measures to counter political terrorism in the country at developmental crossroads.
\end{abstract}

Keywords: Political terrorism, SIT, Arodan dance theatre, Choreographic images, Nigeria

\section{Introduction}

The term 'terrorism' was purportedly first coined in the 1790 s to refer to the shocking acts of terror used during the French Revolution by the revolutionaries against their opponents. Terrorism as a concept

\footnotetext{
*'Tosin Kooshima TUME, Ph.D. is of the Department of Theatre and Media Arts, Federal University, Oye-Ekiti, Nigeria

Email: kooshima.tume@fuoye.edu.ng
} 
has since evolved, and has generally come to be known as the intention to create and spread fear in the populace through the use of either overt or covert violence. The term has many possible meanings, but it basically refers to the intentional and indiscriminate use of violence or intimidation as a tool for the creation of terror among masses of people, in order to realise an unpopular or unconventional aim. While the diverse types of terrorism are defined by their objectives, the aim in pursuit may be religious, political, financial, or ideological.

Generally, acts of terrorism are identifiable within the three broad classes of revolutionary, sub-revolutionary, and establishment terrorism typologies. (britannica.com/topic/terrorism). Research reveals that the most common motivations for terrorism are; civilizations or culture clashes, globalization, religion, the quest for ethnic or political domination. We also have individual-based reasons such as frustration, negligence, deprivation, negative identity, narcissist rage, and/or moral disengagement, as some of the leading causes of terrorism. Furthermore, information garnered from the official website of the Eastern Kentucky University, identifies the basic five types of terrorism thus:

1. State-sponsored terrorism, which consists of terrorist acts on a state or government by a state or government.

2. Dissent terrorism, which are terrorist groups which have rebelled against government,

3. Terrorists and the Left and Right, which are groups rooted in political ideology.

4. Religious terrorism, which are terrorist groups which are extremely religious motivated, and

5. Criminal terrorism, which are terrorists acts used to aid crime and criminal profit. (https://h/sonline.eku.edu/h/s-101-terrorism).

From the foregoing, it is obvious that the act of terrorism is highly calibrated and premeditated in order to assure a shock value. It is likely for this reason that its victims are carefully targeted or selected. The locations where terrorist attacks are carried out are also deliberately chosen in order to achieve spectacular results. The location could either be physical or virtual. While terrorism and crime are different concepts, there is a thin line between them. Usually, the motive serves as the determinant factor of the category involved. However, in as much as both concepts have different modus operandi, a crime can also be counted as an act of terror, if the motive is to intimidate or cow the populace for selfish group interests. Drawing on this, it is safe to surmise that any deliberate group action, either covertly 
or overtly violent, which is deliberately planned to instil fear in a people, qualifies as a terrorist act.

\section{Political Terrorism in Nigeria: What, Why and How?}

Terrorism has a long history in Africa. However, in recent times, it has become a dire and controversial issue in Nigeria. The many faces of terrorism in Nigeria range from the mass killings and suicide bombing acts by the deadly Boko Haram religious sect, the destruction of pipelines and abductions/kidnappings by the Niger Delta militants, to the wanton destruction of human life and properties by the killer herdsmen. These violent acts end up leaving the victims helpless, and the government bewildered, while the perpetrators continue to bask in their seeming invincibility.

Due to the emergent issues, hot debates on the issue of terrorism abound on both the physical and virtual Nigerian spaces. The diverse and conflicting opinions on what constitutes a terrorist act are found to be coloured with the sentiments of political affiliations and ethnic loyalties. Interestingly, class structures are untouched by these arguments. The ruling class has remained somewhat united in the face of this menace which has besieged the Nigerian nation, while the masses take it upon themselves to trade blames along the lines of ethnicity, religion, and political partisanship. This validates the popular notion that, in politics (and for politicians), there are no permanent enemies or friends, just shifting affiliations according to whatever serves current political interests, which to them (politicians), supersedes unfortunately national interests.

As part of their desperate measures to get and perpetually hold on to power, Nigerian politicians are known to cloak political interests with criminal and terrorist acts. This results in an oppressive relationship between the politicians and the electorate. Going by this clarification, deliberate corruption and insincerity on the part of political leaders in order to manipulate masses for electoral purposes, qualify as terrorist acts. Beyond the physical manifestations of the manipulations which the ruling class metes out on the masses, there is an enduring psychological effect that is not only debilitating to the physical wellbeing of the masses, but also their reasoning. Nigerian politicians have been accused of massive plundering of government treasury, lack of empathy for the plight of the masses, gross misrule, blatant corruption, primitive accumulation of wealth and ineptitude. Apart foregoing, which are not unfounded, the Nigerian ruling class are wont to propagandise against their political opponents, and continually set the masses against themselves. This informs Mamadu's position that:

The Nigerian politics is geared towards acquiring wealth and not in the sense of patriotic service to the nation... Before elections are 
done, politicians go to any extent to secure power and achieve their political ambitions. During the time for their campaign rallies, money is displayed and people bribed, while others are paid heavily to assassinate their fellow human beings. (74)

In their quest for political power, Nigerian politicians leave no holds barred. They hold on to the privileges and even rights of the common man, so as to control them. Oshionebo and Mbachaga assert that African countries from post-colonial times have continued to suffer in the hands of the ruling elites who dish out wretched salaries that can't meet the everyday needs of the masses. Whereas, a select set of individuals within the polity enjoy maximum luxury paid from the excruciating taxes and deductions from the wages of the masses. The above is reflective of contemporary political life in African states. The civil unrest and internal conflicts of countries such as Somalia, Dafur, Kenya, Zimbabwe, Congo, and Rwanda is but a confirmation of the struggle between political elite to control power and economic resources so as to be able to control the will of the masses and consolidate their interests (2).

The foregoing assertion aptly captures the current situation in Nigeria, whereby the federal government has failed to review the official minimum wage for years, and most states owe the civil servants salaries of several months, needless to mention the sorry state of pensioners who ought to be senior citizens. Ideally, the minimum wage is expected to be reviewed every four years. However, we are confronted with the realities of insincere efforts towards the review of the minimum wage and the government's noticeable lack of commitment to the welfare of the Nigerian people. Ironically, the Nigerian lawmakers continue to approve outrageously humongous allowances for themselves, thereby enriching their already filled and over-flowing pockets, while they give little or no thought to reviewing the minimum wage of the government workers. Lamentably, this widens the gap between the rich and poor. It has been observed that the middle class in Nigeria has been completely wiped out, what we now have are the two classes; the rich and the poor.

The wages of politicians continue to increase, thereby making political offices extremely attractive, while the civil servants who continue to work without pay are left at the mercy of whatever crumbs they are able to scrimp from the tables of the politicians/ruling class. This makes trained professionals abandon their professions for politics, and makes even jobless people seek political offices at all costs. For it is widely believed that once you are able to get a political office in Nigeria, you are 'made for life.' This unfortunate development has also led to more serious issues of vote selling and buying during 
elections. From the foregoing, it is easy to decipher that these actions on the part of the Nigerian ruling class, is a deliberate and calculated at subduing and oppressing the electorate for political reasons.

In a Facebook post by Ibrahim Khaleel Saleh (IK), a story was recounted of how Adolf Hitler went to a political meeting with a live chicken. At the meeting, Hitler reportedly plucked off the feathers of the chicken one by one. The chicken was said to have quacked in pain as blood oozed from its pores, while Hitler continued plucking its feathers without remorse. When the chicken was completely naked, Hitler threw it on the ground and started throwing chicken feeds at it. The chicken grabbed at the feeds hungrily, and followed Hitler wherever he went. Hitler purportedly then turned to the members of his political party and said:

This chicken represents the people. You must dis-empower them, brutalise them, beat them up, and leave them. If you do this, and then give them peanuts when they are in that helpless and desperate situation, they will blindly follow you for the rest of their life. They will think you are a hero forever. They will forget that, it is you who brought them to that situation in the first place. (Facebook, 9 Sept. 2018, 6.04 p.m.)

This story is an apt illustration of what the Nigerian masses suffer in the hands of their political leaders. Against the background of political manipulation and terrorism on the Nigerian masses, the role which the arts should play in all of this is clear, as art mirrors life. JuliusAdeoye rightly posits that "theatre cannot be divorced from the politics of the society it emanates from." He reiterates that "even though arts and politics stand independently, yet arts is not complete without some political elements" (5). We concur that since art serves as a mirror to the society, it is a worthy medium to reflect on the socio-political realities of Nigeria, commend the rights, identify the wrongs, and proffer possible solutions. It is based on this premise, that this article through an examination of the Arodan dance theatre, attempts a searing expose on the antics of Nigerian political leaders and how their actions amount to subtle and covert terrorism at the expense of the masses. It also explores the possible channels through which counter actions to political terrorism can be achieved in Nigeria. 


\section{The Social Identity Theory and the Yoruba 'Arodan' Conceptual Frame}

The social identity theory is a construct in psychology that postulates that people tend to identify themselves by the traits of the group to which they belong. Henri Tajfel, the proponent of the theory proposed that the groups that people belong to give them a sense of identity in the social space. He further clarifies that people are grouped into ingroups, and out-groups, creating the dichotomy of 'us' against 'them'. Saul McLeod claims that "the central hypothesis of social identity theory is that group members of an in-group will seek to find negative aspects of an out-group, thus enhancing their self-image." (simplypsychology.org/social-identity-theory.html).

In Yoruba worldview, Arodan basically refers to a fool's errand which elders send their errant children to embark on; a futile search quest. It is an oral tradition found in almost all traditional Yoruba societies. It is a strategy used to curb the excesses of troublesome children. As a cautionary or disciplinary conception that parents employ to deal with naughty children, it is used to ensure that the children are not in the know when elders want to embark on an activity without the children's knowledge. Arodan which literally means "tarry forever" is a communal strategy which employs delay tactics to divert suborn children's attention without alerting them. The way of use is simply to send the unsuspecting child on an errand to an elder to 'collect Arodan', the elder in turn creatively sends the erring child to another elder, who in turn sends the child to another elder, and the cycle continues till the child is fagged out from the rigours of his or her fruitless search, and an elder decides to pity him or her. Such a child is then sent back home, and in most situations, the child is so tired that he or she falls asleep immediately he or she gets home. This coded message for mission impossible is also known in varied terms such as 'ewe jokoje,' 'omotoyiogbon,' etc.

The interesting thing about Arodan or its variants is that, it is unrehearsed. However, the effect is like that of a pre-arranged deal, the Arodan sequence does not need prior arrangements or foretelling, one just acts upon it automatically. In Yorubaland, if a child comes to you to ask for Arodan, you simply know that the child has been troublesome and the elder automatically does the needful by keeping the child busy with the never-ending errand. Logically, adults in Yorubaland know this concept as they may have been victims during their childhood, and will not explain it to children. This is because culturally there is a code of silence which surrounds it and the children would now only learn its factuality when they themselves become adults, and they would eventually play it on children in return. Going by the 
analysis of the Yoruba 'Arodan' concept, and the tenets of the social identity theory (SIT), therefore, the Nigerian politicians could be categorised as the 'elders' and members of the in-group, while the electorates could be classified as the 'troublesome children' and members of the out-group. These concepts succinctly capture the fate of the Nigerian citizens at the mercy of their leaders.

\section{Arodan: The Dance Theatre}

Arodan is a dance theatre which is metaphoric and satiric in nature, making use of minimal dialogue, abstract and expressive dance movements. It makes use of the two-fold storytelling technique, whereby two stories unfold simultaneously. One fold employs dialogue and dramatic actions for storytelling, while the other realises its storytelling through expressive dance movements. Put side by side, both folds actually enacts the same story, albeit through different means. The story oscillates between two distinct locales; one on the stage, and strictly for dance movements, and the other on the apron, strictly for dialogue. Actions in both locales dovetail into one another, through quick but smooth transitions throughout all the sequences, such that there is no moment of vacuity throughout the entire performance.

The dance theatre opens at the apron, with a woman, Mama Lagbaja, who is busy counting some money and making some mental calculations of her business. Mama Lagbaja is repeatedly disturbed by Lagbaja, her son, who intermittently makes a loud noise while playing. To achieve solitude, Mama Lagbaja resolves to send her son on the mission impossible of collecting 'Arodan' from her friend, Mama Tamedun. This action leads to a never-ending journey for Lagbaja, as his mother's friends; Mama Tamedun, Mama Lakasegbe, and Mama Lamoorin, continue passing him among themselves like a football. Throughout the performance, these series of actions run concurrently with the other scenes enacted through dance movements on the stage. The next scene reveals a surprise birthday bash held in the honour of Mama Nigeria. While blindfolded, Mama Nigeria is led into the party arena by three leaders of the major ethnic groups in Nigeria. A robust dance performance is performed to the delight of Mama Nigeria. While the performance is ongoing, the three ethnic leaders individually sneak towards the birthday cake with the intention of stealing it. This leads to a struggle which eventually attracts the attention of the military man and his orderlies. With the power of the gun, the military man seizes the cake. He proceeds to lick the cake, while the poor masses groan under the cudgels of the military orderlies. Having licked to his satisfaction, he hands over the cake to one of the ethnic leaders. The other ethnic leaders promptly abandon their followers, and immediately join the chosen ethnic leader in licking the cake by turns. 
As the story unfolds, the ethnic leaders form political parties and canvass for votes from the people. They fortify their political thugs with arms and cash. The thugs in turn intimidate and attack people who belong to opposing parties. An election is conducted, and at the end, chaos bursts out among the party supporters, while the leaders quietly abandon them. As the people engage in post-election battles, the leaders reunite and resume their cake-licking. Eventually, the consequences of the actions and inactions of the political class begin to tell on the poor masses.

The unemployed youths resort to begging for alms, kidnapping, and internet fraud (Yahoo Yahoo) and money rituals, while the female youths embrace prostitution. Ironically, a young man steals in the market due to hunger, and jungle justice is meted out on him, while a politician moneybag who makes money from looting the government purse is felicitated by the same market people. Sadly, the young female corps members who embraced prostitution in order to 'make ends meet' are used for money rituals by politicians and internet fraudsters. This tragedy sparks off rage among the people, and leads to an unprecedented revolution that make the people take charge of their destiny by bringing the corrupt leaders to book.

The choreographic concept in Arodan addresses the theme of insincere leadership, and perpetually gullible followership. It conceptualises how the people have become puppets in the hands of their political leaders. The story explores the idea of the 'Arodan' concept in the Yoruba worldview to portray the corruption of the political class, and the voluntary gullibility of the masses. To buttress the choreographic intention in Arodan, therefore, the choreographic images employed were expressed in terms of visual images through movements, floor patterns, props, costumes, and set designs.

\section{Terrorism and Counter-Terrorism as Choreographic Metaphors in Arodan Production}

Movements: The dance movements in Arodan were purposefully selected sequences of human movements which have aesthetic and symbolic values. The movements were created through the various processes of improvisation, refinement, recreation, and imitation, to reiterate the overall idea of the dance story. Ideas are strong motivating factors for movement creation, thus, the movement vocabulary which was employed justified the choreographic intention of Arodan.

The quality of the movements in the story was deliberately structured to generally enact familiar scenarios on the Nigerian political scene, and provoke thoughts towards positive actions. For the masses, running, crouching, twisting, squatting and collapse movements in 
zigzag directions were utilised to portray their state of helplessness and confusion, while marching, swaying, and perpendicular movements represent the arrogance and flamboyance of the ruling class. The energy level of both parties was also achieved in a sharp contrast. The movements of the masses were slow and sluggish, while the leaders were gay and agile. During the fights enacted by the characters representing the masses, the footwork of the movements were executed in the fast pace to a slow continuum. In doing this, the deceleration movement technique was utilised to portray the intensity with which Nigerian masses start controversies on serious matters, until such issues fade into oblivion without any positive action being taken.

In addition to the series of human actions which were executed in dance movements, the choreographic devices of sharp contrast, counterpoint/call and response, complementary and unison movements further served as drivers for the images of gullibility, recognition, retaliation on the part of the masses. The presence of unity, continuity, variety, contrasts, repetition in the choreography, gradually built the story towards the climax which was achieved with the role reversal between the masses and the leaders. This retrograde technique utilised ballistic movements which saw Lagbaja; the troublesome child, chasing his mother and her friends; the cunning elders, culminated into the masses forcing the political leaders down on their knees, while the masses performed the 'Ajekuniya' song and choreography for them.

\section{Song:}

Ajekuniyaniyoo ye, ajekuniyaniyoo je

Eniti o to niina, ti $n$ de'nade'ni

Ajekuniyaniyoo je... shioor!

\section{Transliteration:}

His suffering shall be legendary, his suffering shall be legendary He who attempts to attack the one who is greater than him His suffering shall be legendary... Shame!

The 'Ajekuniya' song is popularly associated with a Nigerian politician notorious for his unbecoming antics. The song which illustrates the arrogance of the ruling class and their disdain for the common man, was used for motif development, repetition, variation, and progression of the dance story. In the course of the story, the song was performed intermittently as a recurrent motif to drive home the message of the story. The movements performed to 'Ajekuniya' song depict deliberate terrorist actions on the part of the political 
leaders, while the masses are no wiser to their leaders' wiles. Other popular forms of music such as Nigerian hip hop and highlife were employed to link the sequences in the story and to comment on actions in the story. The story ended with a song:

\section{Song:}

Nigeria is ours

It is time to stand up for what is right

Nigeria belongs to all of us

Say no to bad leadership

Say no to passive followership

This is a clarion call which charges all Nigerian citizens to awareness and takes action against political terrorism in the country.

Floor Patterns and Designs: Several shapes and directions for movements were used to create images in the Arodan production. There were several fight situations in the story. The fights occurred among the masses, as they scrambled over the scrubs from the tables of their political leaders, or as they showed support to the political candidates of their choice. The simultaneous, cumulative, and loose cannon choreographic devices were employed to realise the fights movements at different levels and placements. The high and low levels played out oppression from the ruling class to the masses, while the curvilinear and angular placements suggested disintegration and chaos.

During the eventual revolution which projects the call for a counter action to political terrorism, the masses gathered round the leaders in a circle shape to depict togetherness and unity of purpose, as they reclaimed their freedom from the oppressors. The use of circles was to depict oneness and unity of purpose when the masses eventually realise the desperate antics of the politicians. Worthy of mention is the use of levels to portray status and mood. In several instances, the political leaders stood tall, while the masses were down in varied stumbling, falling, and collapsed postures.

Costumes and Props: The choice of costumes in Arodan production was abstract and neutral for symbolic purposes, ease of costume change, and fluid use of performers. All the performers, except for major characters such as Mama Nigeria and the three ethnic leaders, adorned leotards of black colour while the other characters embellished their black adornments with basic and fragments costumes. The basics and fragments costume strategy refers to using a little to depict the whole idea of characters, thus mentally creating in the mind of the 
audience, the existence of the other costume elements which could have been used. For instance, fragmented pieces like a convocation cap used for alms begging, was deployed to depict the character of an unemployed graduate. In a like manner, the official NYSC shirt, a laptop, and some charms worn round the neck of a character clearly depicted the generation of young internet fraudsters who have become a menace to the Nigerian society in recent times. Just as the GreenWhite-Green colours of the Nigerian national flag was used to design a cake to symbolise the national wealth and resources of the country, the same colours were used to make a flamboyant dress for the Mama Nigeria's character. The three ethnic leaders were also identified by the traditional costumes of each of the ethnic groups they represented.

Rhythmic Dramatic Actions and Dialogue: To aid the non-verbal means of communication in the Arodan story. There were bits where rhythmic dialogue and vivid dramatic actions were employed. There was the bit of the politician; a self-acclaimed man of the people, who devised the cunning acts of frying akara and roasting corn with masses, prior to the elections. The brief bits of dialogue add to the images of the usual hanky-panky which the politicians play, and how they toy with the intelligence, feelings, and emotions of the masses. The below excerpt illustrates this point:

Lagbaja: ...My mother sent me to collect arodan from Mama Tamedun, but on getting to her house, she told me that you have collected it. That is why I am here, ma.

M. Lakasegbe: Ha, sangbafo! Arodanke? I just sent it to Mama Lamoorin! She says she needs it urgently. (Sympathetically.) And her house is far oh...

Shebi you know her house? That blue black house that is between the two compounds adjacent the storey building almost behind the market square...

Mama Lakasegbe's description of Mama Lamoorin's house, is a succinct example of the emotional roller-coaster which Nigerian political leaders subject their followers to. Another memorable situation in the story was when in the aftermath of crisis during a political rally, a politician was dressed up in bandages and neck braces by his colleagues. The politician continually wailed "I am in severe pain" to the hearing of everyone, in a bid to get sympathy from the electorate.

\section{Conclusion}

Arodan is a metaphorical enactment of the state of the Nigerian political scene. It reflects the cat and mouse relationship between the Nigerian 
politicians and the masses, as Nigerians who are eagerly expectant of the dividends of democracy are being tossed up and down in the unending manner of a roller-coaster. On the whole, utilising an eclectic fusion of abstract, metaphoric, and representational choreographic styles, Arodan combines movements, songs, music, chants, dialogue, dramatic actions, props, costume, make-up, set design, and lighting to build up a linear storyline. The prevalent images which align with the thematic concerns of the dance story are; the ignorance and gullibility of the masses, and the greed and perpetual wickedness of the leaders, unemployment, point of recognition, and mass revolution. Through a definitive choreographic style, devices are used to create images that align with the generated movements, in order to transport the audience mentally into a journey of the story. The images of unemployment and starvation are crucial to the story, as they are great drivers of crime. Also, studies have shown that the level of crime in any area is almost always in direct proportion to the number of unemployed.

The Arodan story identifies bad leadership as a terrorist strategy which the political leaders adopt to prey on the masses. The ruling class capitalises on ignorance and gullibility on the part of the people to terrorise them. Examples of this are shown in the strategy of unpaid salaries in order to cause hunger and starvation for the masses, so as to perpetuate dependence on the politicians. We also have cases of intelligence manipulation whereby politicians commission white elephant projects and make bogus promises whenever election is near. Political terrorism is real, and the only way to counter this form of terrorism is for the masses to become aware of their rights, and unite in the reality that the political leaders only work for their own selfish interests. The dance theatre seemingly begs a lone question; when will Nigerian citizens wise up enough to stop collecting 'Arodan' from their 'politricking' leaders?

\section{Works Cited}

Adelakun, Abraham. "Cultural Documentation and Structural Analysis." Ed. . OluObafemi and Barclays Ayakoroma. Perspectives on Cultural Administration in Nigeria. Ibadan: Kraft Books Limited, 2011. 64-74. Print.

Encyclopaedia Britannica. "Terrorism." Web. 20 April 2019 <britannica.com/topic/terrorism>.

Eastern Kentucky University. "Terrorism." Web. 20 April $2019<\underline{\text { https:I }}$ /hlsonline.eku.edu/hls-101-terrorism>. 
Julius-Adeoye, 'Rantimi J. "Nigerian Playwrights and the Issue of Official Corruption: A Study of Selected Plays." Ed. Barth Oshionebo and Jonathan D. Mbachaga. Literary Perspectives on Corruption in Africa. Makurdi: Bookworks Publishers, 2010. 3-17. Print.

Mamadu, Titus. T. Corruption in the Leadership Structure of Nigerian Polity. Lagos: Theomadex Ventures, 2006. Print.

McLeod, Saul. "Social Identity Theory." Web. 22 April 2019 <simplypsychology.org/social-identity-theory.html>.

Oshionebo, Barth and Mbachaga, Jonathan D."Introduction." Ed. Barth Oshionebo and Jonathan D. Mbachaga. Literary Perspectives on Corruption in Africa. Makurdi: Bookworks Publishers, 2010. 1-4. Print.

Khaleel, Ibrahim S. "Facebook Recount on Adolf Hitler." 9 September 2018, 6.04 p.m. 